\title{
Bilim, Teknoloji, Mühendislik ve Matematik Alanlarında Kadın Olmak: Cinsiyete Yönelik Yargıları Kırma
}

\author{
Women in Science, Technology, Engineering and Mathematics: Breaking \\ Gender Stereotypes
}

\section{Tansu MUTLU* Fidan KORKUT OWEN**}

\begin{abstract}
Öz: Bilim, Teknoloji, Mühendislik ve Matematik (FeTeMM) alanlarını seçen, bu alanlarda öğrenim gören ve çalışma hayatında yer alan kadınların oranları erkeklere göre oldukça düşüktür. FeTeMM alanlarındaki cinsiyetler arasındaki farkın nedenlerini inceleyen araştırmaların pek çoğu toplumsal cinsiyet rollerine dikkat çekmektedir. Bu saptamadan yola çıkarak, bu araştırmanın amacı Türkiye'de FeTeMM alanlarında çalışan kadınların kariyer gelişimlerine ilişkin görüşlerini toplumsal cinsiyet rolleri açısından betimlemektir. FeTeMM alanlarında çalışan kadınların, bu alanları seçme, eğitim alma ve çalışma sürecinde toplumsal cinsiyet rollerinden nasıl etkilendiklerine dair görüsslerinin incelendiği çalışmaya 16 kadın katılmıştır. Amaçlı örneklem yöntemlerinden maksimum çeşitlilik örneklemesi kullanılarak belirlenen katılımcılardan yazılı görüş alınarak elde edilen verilerin analizinde içerik analizi yöntemi kullanılmıștır. Bulgulara göre, kadınlar her üç aşamada da toplumsal cinsiyet rollerinin etkisinden söz etmişlerdir. Ayrıca alan seçimleri sırasında en çok aile üyelerinin, alan eğitimleri sırasında eğitim yaşantılarının, çalışma yaşamlarında ise iş/çalışma ortamı aracığıyla toplumsal cinsiyet rollerinin kariyer gelişimlerini etkilediğini belirtmişlerdir. Ayrıca, katılımcılar bu alanlarda kariyer yapacak kadınlara yönelik bazı önerilerde bulunmuşlardır.
\end{abstract}

Anahtar sözcükler: Toplumsal Cinsiyet Rolleri, Kadın, Kariyer Gelişimi, Fen, Teknoloji, Mühendislik ve Matematik Alanları

Abstract: There is gender inequality in the choice of Science, Technology, Engineering and Mathematics (STEM) fields, entry into STEM college majors and participation in a workplace environment in STEM fields over the course of time. Many studies aiming to understand the gender imbalance in STEM fields have focused on the role of gender. Because of this, the aim of this study is to examine women' career development in STEM fields within the context of gender roles based on their perceptions. With this aim, the perceptions of 16 women in STEM were examined to understand how the role of gender influences them in three stages (college major choice, undergraduate education and working life) of their career development. Qualitative content analysis was used to analyze the responses of participants who were selected by using using the maximum variation sampling method that is one type of the purposeful sampling methods. The participants stated that cultural values played role in all three stages (college major choice, undergraduate education and working life) of their career development. And, family members had a role in the college major selection because of the role of gender, while learning experiences took an active role in one stage (undergraduate education) of their career development in STEM. Both the work climate and cultural values were important components of decision making to persist in or depart from STEM fields because of the role of gender. Women in STEM fields have suggested that women who are eager to choose a STEM career should get training while working and obtain more knowledge about themselves before choosing a STEM career major

Keywords: Gender Role, Women, Career Development, STEM Fields

\footnotetext{
* Arş. Gör., Eskişehir Osmangazi Üni., Psikolojik Danışmanlık ve Rehberlik ABD, Eskişehir. tansumutlu@gmail.com

** Prof. Dr., Bahçeşehir Üni., Psikolojik Danışmanlık ve Rehberlik ABD, İstanbul. fdnkrkt@gmail.com
} 


\section{Giriş}

Son zamanlarda bilim, teknoloji, matematik ve mühendislik (FeTeMM) alanlarının popüler olması bu alanlarda yetişmiş ve bu alanlarda kariyerini sürdüren, nitelikli insanlara daha fazla ihtiyaç duyulmasına neden olmuştur (Başaran-Symes 2015). Giderek artan ihtiyaca paralel olarak FeTeMM alanlarını tercih eden, bu alanlarda öğrenim gören ve kariyerini sürdüren birey sayısı da artmaktadır. Bu alanlarda kariyer yapmayı tercih eden, öğrenim gören ve çalışan kadınların sayısının artırılmasına yönelik çabalar olmasına rağmen (AAUW 2010), bu alanları tercih eden kadınların sayısı erkeklere göre beklenenden oldukça azdır (National Science Foundation 2010; 2015). Farklı araştırma sonuçlarına göre Amerika Birleşik Devletleri'nde (ABD) FeTeMM alanlarında eğitim alan ve FeTeMM mezunu olarak çalışan kadınların sayısındaki artışa rağmen bu alanlardaki cinsiyet farkı uçurumu varlığını sürdürmektedir (Perez-Felkner et al. 2001,1658; Chen \& Weko, 2009; National Science Foundation, 2015). FeTeMM alanlarını tercih eden kadınların oranları erkeklere göre hala oldukça azdır (National Science Foundation 2015). Sayısal yeteneği olan kadın öğrenciler bile bilim alanlarını erkeklere oranla daha az tercih etmekte ve bunun bir sonucu olarak söz konusu uçurum varlığını sürdürmektedir (Perez-Felkner et al. 2012). FeTeMM alanlarını seçmeyi planlayan kadınların yüzdelerine dair benzer bir tablo FeTeMM alanlarında öğrenim görme sürecinde de ortaya çıkmaktadır (AAUW 2010; Brandt 2014). Örneğin, FeTeMM alanlarını seçen bazı kadın öğrenciler henüz alanla ilgili herhangi bir etkinliğe katılmadan ve aldıkları kararın sonuçlarının neler olabileceğini görmeden bu alanlarda öğrenim görmekten vazgeçmektedirler (AAUW 2010). Özellikle fizik, mühendislik ve bilgisayar alanlarında vazgeçme oranı gün geçtikçe daha da artmaktadır (Dasgupta \& Stout 2014). Örneğin 2008 yılında fizik alanında lisans eğitimini tamamlayan öğrencilerin sadece \%20,3’ü kadındır (National Science Foundation 2010). Brandt (2014) ise yaşam bilimleri hariç diğer FeTeMM alanlarında kadınların erkeklere göre daha az temsil edildiklerini ve bu alanlardan mezun olan kadınların oranının \%20 ya da daha az olduğunu belirtmektedir. FeTeMM alanlarında çalışan kadınların yüzdeleri incelendiğinde benzer bir durumun iş dünyasında da var olduğu görülmektedir (Simard 2008). Bu alanlarda çalışan kadınların yarısından fazlası biyoloji alanındayken onu matematik ve bilgisayar alanları izlemektedir. FeTeMM alanları arasında çalışan kadın oranının en az olduğu alan ise mühendisliktir. Ayrıca mühendislik alanı incelendiğinde, ABD'de tüm mühendis işgücü içinde kadınlar sadece \%15 ile temsil edilmekte ve sayıları giderek azalmaktadır (Schelmetic 2013). FeTeMM alanlarında çalışan kadınların az olduğu gerçeği tüm Avrupa'da da karşımıza çıkmaktadır (Accenture 2014). Kiwana, Kumar ve Randerson (2011), European Labour Force Survey sonuçlarına göre farklı ülkelerdeki kadın mühendis oranların1, Latvia \%30, Bulgaristan \%29.3, Kıbrıs \%28.6, İsveç \%25.9, Türkiye \%21, İtalya, \%19.5, İrlanda \%14.3, Avusturya \%10 ve İngiltere'de \%8.7 olarak rapor etmektedirler. Türkiye'de kadınların işgücüne katılımları \%27.4 ile OECD ülkeleri arasında en düşük düzeyde (Ercan 2011) olsa da Türkiye'de mühendislik ve teknoloji alanlarında çalışan kadınların oranı \%20 civarında (Okay 2013) olduğu rapor edilmektedir. Bu yüzdelere göre Türkiye'deki oranlar ABD'deki oranlara yakın ve bazı Avrupa ülkelerine göre ise daha iyi durumdadır.

FeTeMM alanlarında cinsiyetler arasındaki bu farkı açıklamaya yönelik yapılan pek çok araştırma alanyazında yer almaktadır. Bu açıklamalardan birinde cinsiyetler arasındaki bu fark ergenlerin toplumsal cinsiyete dair kalıp yargıları, FeTeMM alanlarına ilişkin yeteneklerini sorgulamaları ve bu sorgulamalar nedeniyle bu alanlarda kariyeri tercih etmeye yönelik isteklerinin olmayışıyla (Burchinal et al. 2008) açıklanmaktadır. Söz konusu farkı ergenlerin cinsiyet farklılıklarına ilişkin önyargılarla karşılaşıp akademik başarılarının düşmesiyle (Johnson et al. 2012), ilgili alanlarda kariyerini sürdüren kadın oranlarının erkeklere göre daha az olmasıyla açıklayanlar (Dasgupta, Scircle \& Hunsinger 2015) da bulunmaktadır. Ayrıca eğitim ortamlarında erkek 
sayısı fazla olduğu için kadınların etkinliklere katılmaması ve bu alana kendilerini ait hissetmemeleri de (Blake-Beard et al. 2011; Dasgupta \& Stout 2014) açıklamalar arasındadır. Bunlara ek olarak cinsiyetler arası farkı, ev ve iş yükümlülüklerinin fazla olmasıyla ve bu yükümlülüklerinin kadınların karşılaması gerektiğine ilişkin kalıp yargılarla (Glass et al. 2013) açıklayan çalışmalar da vardır.

FeTeMM alanlarındaki cinsiyetler arasındaki farkın büyük olmasının nedenlerini araştıran araştırmacıların pek çoğu cinsiyetlerle ilgili kalıp yargılar üzerinde odaklanmaktadır (AAUW 2010; Deemer et al. 2014). Niles ve Harris-Bowlsbey (2009) kadınların kariyer gelişimleri süresince karşılaştıkları güçlükleri cinsiyet rollerinin toplumsallaştırılmasının olumsuz sonucu olarak değerlendirmektedir. Bu toplumsallaşma sırasında birçok mesleğin doğrudan belli bir cinsiyetle özdeşleştirilmesi, cinsiyet rollerine ilişkin yargıların pekiştirilmesine ve bunun sonucu olarak iş gücünün cinsiyete göre dağılmasına neden olmaktadır (Herr, Cramer \& Niles 2004). Özellikle kadınların FeTeMM alanlarına ilişkin yeteneklerin olmadığına dair kalıp yargılar (Leaper \& Brown 2008), FeTeMM alanlarının kadınlara yönelik olmadığına dair kalıplaşmış önyargılar (Hartman \& Hartman 2008) ve kadın oranlarının düşük olması nedeniyle kadınların kendilerini yetkin görmemeleri ve bu alanda aktif olmamaları (Dasgupta, Scircle \& Hunsinger 2015) kadınların bu alanlarda kariyer yapmalarına engel olmaktadır. Çünkü cinsiyetleştirilmiş kalıp yargılar kadınların FeTeMM alanlarını seçme, bu alanlarda öğrenim görme ve çalışma süreçlerinde onların mesleki sonuç beklenti ve öz-yetkinlik inanç düzeylerini olumsuz yönde etkileyerek (Fouad \& Santana 2016) bu alanlarda kariyer istemelerine ve kariyerlerini sürdürmelerine mani olmaktadır.

\section{Teorik Literatür}

$\mathrm{Bu}$ kısımda öncelikle bu çalışmanın kuramsal temelini oluşturan toplumsal cinsiyet rollerine ilişskin kuramsal açıklamalara yer verilmektedir. Sonrasında ise Sosyal Bilişsel Kariyer Kuramından söz edilmektedir. Kuramsal açıklamaların ardından bu kuramları temel alan araştırmalara dayalı olan sonuçlar özetlenmektedir.

\section{Toplumsal Cinsiyet Rollerine İlişkin Kuramlar}

Biyolojik cinsiyetten farklı olarak cinsiyetin toplumsallaşması süreci aslında bebeğin doğumuyla başlamakta ve toplumsal cinsiyet rolleri, aile ve medya gibi farklı kaynakların yardımıyla öğrenilmektedir. $\mathrm{Bu}$ süreçte bireyler biyolojik cinsiyetlerine uygun olduğu düşünülen normları ve beklentileri öğrenerek içselleştirmektedirler (Giddens 2012). Başka bir deyişle; bireyler kadın veya erkek cinsiyetiyle doğarlar ve sosyalleşme süreci ile toplumun cinsiyetlerine özgü beklediği roller çerçevesinde kız veya erkek çocuk olmayı öğrenerek büyürler (Terzioğlu \& Taşkın 2008). Dolayısıyla toplumsal cinsiyet rollerini açıklayan kuramlardan birisi Bandura'nın (1977) sosyal bilişsel öğrenme kuramıdır. Bunun yanı sıra toplumsal cinsiyet rollerinin açıklandığı bir dizi kuram da bulunmaktadır. Örneğin psiko-analitik kuram (Chodorow 1998); sosyal öğrenme ve bilişsel gelişim kuramlarının birleştirilmesi ile oluşturulan toplumsal cinsiyet şemas1 kuramı (Bem 1983), genel cinsiyet şeması (Martin \& Halverson 1981; Martin 1993) toplumsal cinsiyet şemasıyla bilgi işleme kuramı, sosyal rol kuramı (Eagly 1987), benlik sunuşu kuramı (Deaux \& Major 1987) gibi bir dizi kuram bulunmaktadır. Bu kuramlar bağlamında araştırmaya konu alan kavramlar incelendiğinde toplumsal cinsiyet rollerine ilişkin kalıp yarg1lar ön plana çıkmaktadır. Dökmen (2004), toplumsal cinsiyet kalıp yargılarını toplumun, kadın ve erkeklerden göstermelerini beklediği özellikler olarak tanımlamaktadır. Toplumsal cinsiyet kalıp yargıları, kariyer seçme sürecinde (Burchinal et al. 2008; Hartman \& Hartman 2008; Leaper \& Brown 2008; Deemer et al. 2014) bireyi farklı biçimlerde etkileyebilmektedir. Bu 
konudaki bilgiler metin boyunca verilmiş ve tartışmalarda kullanılmıştır. Bu araştırmada toplumsal cinsiyet rolleri konusunda daha çok bu rollerin kültür içinde modeller ve pekiştireçler aracılığ 1 ile modeller ve pekiştireçler aracılığı ile öğrenildiğini savunan, sosyal bilişsel öğrenmeye dayalı olan açıklamalar dikkate alınmıştır.

\section{Sosyal Bilişsel Kariyer Kuramı}

Bireylerin kariyer seçimlerini anlama konusunda farklı kuramlar farklı açıklamalar getirse de bu çalışmada temel alınan Sosyal Bilişsel Kariyer Kuramı (SBKK) kariyer seçimini etkileyen etmenler üzerine pratik bazı görüşler sunmaktadır. SBKK, FeTeMM alanlarının seçimi konusunda da kapsamlı bir bakış açısı sunmaktadır (Lent, Brown \& Hackett 1994; Wang \& Degol 2013; Mueller, Hall \& Miro 2015). Bandura'nın (1987) sosyal bilişsel öğrenme kuramındaki öz-yeterlik inançları, sonuç beklentileri ve kişisel hedeflerle ilgili üçlü modelden esinlenerek geliştirilen SBKK, bireylerin kariyer gelişimlerinde ve kariyer kararı vermelerinde bilişsel etmenlerin önemli bir rol oynadığı sayıltısına dayanmaktadır (Lent \& Brown 2002). Sonuç olarak bu kuramsal bakış açısı bireylerin kariyerle ilgili özyeterlik inançlarını, sonuç beklentilerini, ilgilerini, çevresel destek ve engelleri algılaması ile kişisel hedefleriyle ilgili olan seçim davranışlarını ele alarak bireylerin kariyer gelişimlerini açıklamaktadırlar (Lent, Sheu, Gloster \& Wilkins 2010).

\section{FeTeMM alanlarını Seçme Sürecinde Cinsiyetler Arasındaki Farkın Nedenleri}

Bireyler FeTeMM alanlarının temelini oluşturan fen bilimleri ve matematik alanlarına ilişkin özyetkinlik inançlarını ergenlik döneminde oluşturmaya başladıkları (Fouad \& Santana 2016) için ergenlik dönemi kariyer gelişimindeki en önemli aşamalardan biri olarak ele alınmaktadır. Bu nedenle ergenlik döneminde kariyer alanlarını seçme sürecinde bireylerin hangi etmenleri göz önünde bulundurarak tercihler yaptıklarının incelenmesi gerekmektedir. Alanyazında ergenlik döneminde kadınların erkeklere göre FeTeMM alanlarını neden daha az tercih ettiklerine ilişkin farklı açıklamalar yer almaktadır. Örneğin yapılan bir meta-analiz çalışmasında FeTeMM alanlarındaki kadınların ve erkeklerin bu alanda var olma nedenleri açısından cinsiyetler arasında istatistiksel olarak anlamlı farklar olduğu bulunmuştur (Su, Rounds \& Armstrong 2009). Araştırmanın sonuçları FeTeMM alanlarındaki kadın erkek sayısı farkının mesleki ilgilerle açıklanabileceğini göstermektedir. Başarı açısından bakıldığında matematik ve mühendislik alanlarında kadınlarla erkekler arasında başarı farkı bulunmamakla beraber, ilgilerdeki ve öz-yeterlilik algılarındaki farkların FeTeMM alanlarına yönelmedeki farkın kaynağı olabileceğini gösteren çalışmalar da vardır (Inda, Rodriguez \& Peňa 2013; Wang \& Degol 2013).

Türkiye'de yapılan bir çalışmada kadın öğrencilerin, bölüm seçerken bölümün cinsiyetlerine uygunluğuna daha fazla önem verdiklerinin bulunmasına (Korkut-Owen et al. 2012) dayanarak kadınların FeTeMM alanlarına daha az yönelmelerinin toplumsal cinsiyet rolleri ile açıklanabileceğini düşündürmektedir. Mühendisliğin erkeklere uygun alan olarak algılanmasının yanı sıra sıkıcı ya da el gücü gerektiren alanlar olarak algılanması, okul psikolojik danışmanlarının, öğretmenlerin ve ana babaların kız öğrencileri bu alan için desteklememeleri (Fouad et al. 2010; Schelmetic 2013) ve çevrelerinde yeterince kadın mühendis modelinin olmaması da (Schelmetic 2013) diğer nedenler olarak gösterilmektedir. Ayrıca FeTeMM alanlarını seçme sürecinde cinsiyetlerine yönelik kalıp yargılarla karşılaşan bireylerin bu süreçte psikolojik ve sosyal olarak destek alamamalarl (Cheryan et al. 2011; Grossman \& Porche 2014) ve FeTeMM alanlarında kariyeri olan, rol model olarak görebilecekleri ebeveynlerine sahip olamamaları (Ceci et al. 2015) onların bu alanlarda kariyer seçmelerine engel olmaktadır. Özellikle ailelerin çocukların akademik başarılarına ve yeteneklerine yönelik yorumlarda bulunurken cinsiyete dayalı yorumlar yapmaları ve cinsiyetlerle ilgili kalıp yargılara göre tutum sergilemeleri kız öğrencilerin 
FeTeMM alanlarını seçmemelerine neden olmaktadır (Gunderson et al. 2012; Harackiewicz et al. 2012). Kadınların FeTeMM alanları dışındaki alanlara yönelmelerinin nedenlerinden birinin farklı değer ve tercihlere sahip olmalarıyla açılayanlar da vardır. Örneğin Hakim $(2002,431)$ kadın ve erkeklerin iş odaklı olma, ev odaklı olma konusunda farklı olduklarını belirterek kadınların daha çok ev odaklı olma eğiliminde oldukları için FeTeMM alanlarına yönelmediklerini düşünmektedir. Ancak kadınların sayısının daha fazla olduğu hukuk, tıp ve iş dünyasında çalışmanın da çok zaman alıcı işler olmaları nedeniyle bu açıklama kadınların neden FeTeMM alanlarına daha az yöneldiklerini açıklayamadığ 1 için (England 2010) eleştirilmektedir.

Özetle, kadınların FeTeMM alanlarını seçme süreçlerinde pek çok etmen rol oynamaktadır. Araştırma bulguları bütüncül olarak değerlendirildiğinde, kadınların kararlarında özellikle cinsiyete ve mesleklere ilişkin cinsiyetleştirilmiş önyargıların diğer etmenlere göre daha çok belirleyici rol üstlendiği söylenebilir. Kadınlar, FeTeMM alanlarını seçip seçmeyeceklerine sosyal çevrelerinden, ailelerinden ve medyadan aldıkları cinsiyete dayalı önyargılar temelinde oluşturulmuş mesajları göz önünde bulundurarak karar verebilmektedirler. Ayrıca, sosyal çevrede FeTeMM alanlarında kariyer gelişimini sürdüren bireylerin olmayışı ve sosyal çevredeki bireylerin bu alanları seçmeyi planlayan kadın öğrencilere destek sunmayışı kadınların kararlarını etkileyen diğer etmenler arasında yer almaktadır.

\section{FeTeMM Alanında Öğrenim Görme Sürecinde Cinsiyetler Arasındaki Farkın Nedenleri}

Schelmetic (2013) mühendislik programlarındaki kadın öğrencilerin erkekler kadar iyi ya da erkeklerden daha iyi derecelerle mezun olduklarını belirterek daha az kadının mühendislik alanını seçmesinin nedenlerinin akademik olmaktan çok toplumsal cinsiyet rolleriyle ilişkili olduğunu belirtmektedir. FeTeMM alanlarından özellikle bilgisayar, mühendislik ve fen bilimleri alanlarında öğrenim görmeyi seçen kadınlar bu alanlarda öğrenim görürken kendilerini bu alana ait hissetmedikleri için bu alanlarda akademik başarıları erkeklere göre daha düşük düzeyde olmakta ve bunun sonucu olarak da bu alanlardaki eğitimlerini sonlandırmayı düşünmektedirler (Blake-Beard et al. 2011; Stout et al. 2011; Dasgupta \& Stout 2014). Kadınların öğrenim görürken kendilerini bu alanlara ait hissetmemelerinin en önemli nedenlerinin FeTeMM alanlarının kadınlara uygun alanlar olarak görülmeyişi ve cinsiyet farklılıklara ilişkin kalıp yargılar (Nosek, Banaji \& Greenwald 2002) ve bu alanla ilişkili özyetkinlik inanç düzeyi (Blake- Beard et al. 2011) olduğu savunulmaktadır. Bu kalıp yargılar kadınların bu alanlardaki öğrenim görmesine, bu alana ait hissetmesine ve bu alanda yüksek akademik başarıya sahip olmasına engel olmaktadır (Stout et al. 2013; Dasgupta \& Stout 2014).

FeTeMM alanlarında öğrenim gören kadınların sayıca erkeklerden az olması öğrenim yaşantılarını olumsuz yönde etkilemektedir. Dasgupta, Scircle ve Hunsinger (2015) yaptıkları araştırmada kadın öğrenciler grup çalışmalarında erkeklerden sayıca az oldukları için kendilerini daha az yetkin gördüklerini ve bunun bir sonucu olarak takım çalışmasına erkekler kadar dâhil olamadıklarını bulmuşlardır. Çünkü kadınlar herhangi bir grup çalışmasında grup arkadaşlarının karşı cinsiyetten olduklarını gözlemlediklerinde ve o grupta kendilerini azınlıkta hissettiklerinde kendilerini daha az yetkin görmekte ve bunun bir sonucu olarak grup çalışması içindeki akademik başarı ve memnuniyet düzeyleri düşmektedir (Murphy, Steele \& Gross 2007; Meadows \& Sekaquaptewa 2011). Öğrenme yaşantılarına dikkat çeken Wang ve Degol (2013) ise kadın ve erkeklerin FeTeMM alanlarına karşı farklı tutumlarının olmasında okullarda FeTeMM ile ilgili derslerin ve etkinliklerin öğretilme biçimlerinin ve ögretmen öğrenci ilişkisinin önemli olduğunu belirtmektedirler. Öğretmen öğrenci ilişkisi etkisiz olduğunda kadınlar matematik ve fen bilimleri derslerinden kolayca uzaklaşmaktadırlar. Ailenin de kızlarından ve oğullarından beklentilerinin, onlara inanışlarının farklı olmasının, onlara farklı davranmalarının ve özellikle 
sosyo-ekonomik düzeyin cinsiyetler arasındaki matematik ve fen bilimlerine yönelmedeki farkın kaynaklarından bazıları olabileceği düşünülmektedir (Wang \& Degol 2013).

Kadınların FeTeMM alanlarındaki eğitim yaşantıları onların FeTeMM alanlarında kariyerlerini sürdürüp sürdürmeyeceklerine dair kararı etkilemektedir. Çünkü FeTeMM alanlarındaki eğitim sürecinde aldıkları bu kararda pek çok etmen rol üstlenmektedir. Özellikle cinsiyet rollerine ilişkin ön yargılar tıpkı FeTeMM alanlarını seçme sürecinde olduğu gibi eğitim sürecinde de etkili olmaktadır. Sınıf içi ve dışı ortamlarda kadın öğrencilere gösterilen cinsiyetleştirilmiş kalıp yargılarla bütünleştirilmiş tutum ve davranışlar kadınların bu alanlarda eğitim görmekten vazgeçmelerine neden olabilmektedir. Ayrıca eğitim yaşantıları sırasında aldıkları mesajları destekleyen toplumdan ve aile üyelerinden alınan mesajlar da kadınların bu alanlarda eğitim görmek istememelerine yol açabilmektedir.

\section{FeTeMM Alanında Çalışma Sürecinde Cinsiyetler Arasındaki Farkın Nedenleri}

FeTeMM alanlarında çalışan kadınların erkeklere göre daha az olmasının en önemli nedenlerinden birisi işe alım ve iş yerinde yükselme sürecinde cinsiyete dayalı uygulamaların var olması olarak görülmektedir (Kocacık \& Gökkaya 2005; Dasgupta \& Stout 2014). Bu duruma MossRacusin, Dovidio, Brescoll, Graham ve Handelsman'ın (2012) araştırmalarında buldukları sonuçlar örnek olarak verilebilir. Moss-Racusin ve arkadaşları (2012) fen fakültelerinde çalışan öğretim üyelerinin laboratuvarda yönetici olacak kişinin seçim sürecinde cinsiyete dayalı önyargılarının olup olmadığını öğrenmek için yürüttükleri araştırmalarında, öğretim üyelerinin erkek adayları kadın adaylara göre daha yetkin, yükselmeyi ve daha fazla maaş almayı hak eden bireyler olarak değerlendirdiklerini bulmuşlardır. Alanyazında kadınların bu alanlardaki çalışma ortamlarında daha az bulunmalarında kendilerinin bu alanları kadınlara uygun bir alan olarak görmemelerinin ve bu alanlara kendilerini ait hissetmemelerinin payı olduğuna (National Research Council 2009; Blake-Beard et al. 2011) ilişkin bulgulara yer veren araştırmalar bulunmaktadır. $\mathrm{Bu}$ alanların kendilerine uygun olmadığını düşünen kadınlar ihtiyaç duyduklarında iş arkadaşlarından ya da yöneticilerden destek alamadıklarını hissettiklerinde bu alanlardaki kariyerlerini sonlandırmayı düşünmektedirler (Xu 2015). Ev yaşamında yükümlülüklerin erkeklere göre daha fazla olması ve FeTeMM alanlarındaki iş yükünün diğer alanlara göre daha fazla olması kadınların çalışma yaşamlarında ev - iş dengesini kurmalarına engel olmaktadır (Kocacık \& Gökkaya 2005; Glass et al. 2013). Dolayısıyla ev ve iş yaşamı arasında dengeyi kuramamak bu alanlardaki kadınların FeTeMM alanlarında kariyerlerini devam ettirmekte güçlük çekmelerinin başka bir nedeni olarak gösterilmektedir (Cha 2010; Glass et al. 2013).

Sonuç olarak, FeTeMM alanlarındaki kadınlar bu alanları seçerken ve bu alanlarda eğitim görürken yaşadıkları deneyimlere benzer deneyimleri çalışırken de sahip olmaktadırlar. Diğer süreçlere benzer bir biçimde cinsiyetlere dayalı kalıp yargılar içeren tutumlarla, davranışlarla ve sözlerle karşı karşıya kalan kadınlar FeTeMM alanlarında çalışmak istememektedirler. Özellikle işe alım ve işte yükselme sürecinde cinsiyetleştirilmiş kalıp yargıların yeteneklerinin ve özgeçmişlerinin öne geçtiğini gören kadınların bu alanlara kendilerini ait hissetmedikleri için motivasyon düzeyleri düşmekte ve bunun bir sonucu olarak da bu alanları kadınlara uygun bir alan olarak değerlendirmemektedir.

FeTeMM alanlarındaki bireylerin kariyer gelişimleriyle ilgili alan yazın incelendiğinde FeTeMM alanlarındaki kadınların sayıca erkeklere göre daha az oluşu ve kariyer gelişimleri sırasında yaşadıkları sorunlar yurtdışı ve yurtiçinde yapılan bazı çalışmalar tarafından ortaya konmuştur (Ost 2010; Schelmetic 2013; Wang \& Degol 2013; Akgündüz \& Ertepınar 2015; Korkut-Owen \& Mutlu 2016). Öte yandan hâlihazırda FeTeMM alanlarında çalışan kadınların 
FeTeMM alanlarını nasıl seçtiklerinin ve bu seçim sürecinde hangi etmenlerden etkilendiklerinin araştırmacılar tarafindan bütüncül bir biçimde ele alınmadığ 1 (Grossman \& Porche 2014) görülmektedir. Bu nedenle bu araştırmanın amacı Türkiye'de FeTeMM alanlarında çalışan kadınların kariyer gelişimlerine ilişkin görüşlerini toplumsal cinsiyet rolleri açısından betimlemektir. Bu amaçla bu çalışmada FeTeMM alanlarında çalışan kadınların, FeTeMM alanlarını seçme, o alanlarda eğitim alma ve çalışma sürecinde toplumsal cinsiyet rollerinin onları nasıl etkilediğine ilişkin görüşleri incelenmiştir. Bu inceleme sırasında aşağıda yer alan sorulara yanıt bulunmaya çalışılmıştır: FeTeMM alanlarında çalışan kadınların:

a) FeTeMM alanlarını seçerken toplumsal cinsiyetin rolüne ilişkin görüşleri nelerdir?

b) FeTeMM alanlarında eğitim alırken toplumsal cinsiyetin rolüne ilişkin görüşleri nelerdir?

c) FeTeMM alanlarında çalışırken toplumsal cinsiyetin rolüne ilişkin görüşleri nelerdir?

d) Bu alanı seçmeyi planlayan kadınlara önerileri nelerdir?

\section{Yöntem}

\section{Araştırma Deseni}

Türkiye'de FeTeMM alanlarındaki kadınların kariyer gelişimleri üzerinde toplumsal cinsiyetlerinin rolüne ilişkin görüşlerini incelemeyi amaçlayan bu araştırma nitel bir durum çalışmasıdır. Olgu bilim deseni kullanılarak tasarlanan bu araştırmada katılımcıların kariyer gelişimleri bir olgudur. Bu olgu üzerinde cinsiyetin nasıl bir rol oynadığına ilişkin daha ayrıntılı bir bilgiye ihtiyaç duyulduğu için olgu bilim deseni kullanılmıştır (Yıldırım \& Şimşek 2013).

\section{Çalışma Grubu}

Araştırmada görüşme yapılacak kadınlar belirlenirken amaçlı örneklem yöntemlerinden maksimum çeşitlilik örneklemesi kullanılmıştır (Yıldırım \& Şimşek 2013). Bu doğrultuda araştırmaya katılacak kadınların araştırma amacıyla yakından ilgili niteliklere sahip olmalarına özen gösterilmiştir. Amaçlı örneklem yöntemi kullanılırken a) kadın olmak b) FeTeMM alanlarını seçmiş, eğitim almış ve bu alanlarda hâlihazırda çalışıyor olmak ve c) gönüllü olmak üzere üç ölçüt belirlenmiştir. Bu ölçütler kullanılarak FeTeMM alanlarının her bir alt alanında en az bir katılımcı olmak üzere toplam 16 kadın katılımcı belirlenmiştir. Çoğu özel bir şirkette çalışan 16 kadından dokuzu $(\% 56,25)$ lisans mezunu iken yedisi $(\% 44.75)$ yüksek lisans mezunudur. Sadece bir katılımcı doktora mezundur. Katılımcılar Türkiye'de eğitim-öğretim faaliyetlerini sürdüren yedi farklı yükseköğrenim kurumunun $F e T e M M$ ile ilgili bölüm ve programlarından 1993 - 2013 yılları arasında mezun olmuştur.

\section{Veri Toplama Aracı}

Araştırmacılar tarafından Türkiye'de FeTeMM alanlarında çalışan kadınların kariyer gelişimlerine ilişkin görüşlerini toplumsal cinsiyet rolleri açısından betimlemek için bir yazılı görüş alma formu oluşturulmuştur. Veri toplama aracında yer alan dört soru, FeTeMM alanlarındaki kadınların kariyer gelişimleriyle ilgili alanyazına dayalı olarak geliştirilmiştir. Görüşme formunda yer alan açık uçlu sorular "FeTeMM alanlarını seçtiğiniz süreçte cinsiyetinizin rolü neydi?", “FeTeMM alanlarında ögrenim gördügünüz süreçte cinsiyetinizin rolü neydi?”, "FeTeMM alanlarında çalışırken cinsiyetiniz nasıl bir rol oynuyor?" ve "FeTeMM alanlarında kariyer yapmayı planlayan kadınlara önerileriniz nelerdir?” biçimindedir. 


\section{İşlem}

$\mathrm{Bu}$ araştırmada elde edilen verilerinin toplanması sırasında araştırmacılar tarafından geliştirilen yazılı görüş alma formu kullanılmıştır. Araştırmaya katılan katılımcılar Türkiye'nin farklı coğrafi bölgelerinde FeTeMM alanlarında çalıştığı ve bu nedenle yüz yüze görüşme konusunda sıkıntı yaşanacağı için katılımcılardan görüşme formlarında yer alan sorulara yazılı olarak cevap vermeleri istenmiştir. Görüşme formunu yazılı olarak doldurmayı ve araştırmacılara formu geri göndermeyi kabul eden 16 gönüllü kadına görüşme formları gönderilmiştir. Her bir FeTeMM alanından en az iki katılımcıya ulaşılmak istendiği için ulaşılan katılımcılara araştırmaya gönüllü olarak katılabilecek kadın tanıdıkları olup olmadığı sorulmuştur. Katılımcıların öneri sunduğu kişiler arasında görüşme formunu yazılı olarak doldurmayı ve araştırmacılara formu geri göndermeyi kabul eden katılımcılara form gönderilmiştir. Araştırmanın ilk basamağında ulaşılan katılımcılara ise araştırmacıların tanıdığı ya da kadın çalışmalarıyla ilgilenen kadın araştırmacılarla bağlantısı olan kadınlar aracılığıyla ulaşılmıştır. Katılımcılar yazılı görüş alma formunda yer alan soruları yazılı olarak yanıtladıktan sonra formu e-posta aracılığıyla araştırmacılara göndermiş̧ir.

\section{Verilerin Analizi}

Katılımcılardan elde edilen verilerin altında yatan kavramlara ulaşmak ve bu kavramlar arasındaki ilişkiler ortaya çıkarılmak istendiği için Miles ve Huberman (1994) tarafından önerildiği gibi veriler içerik analizi yaklaşımlarından biri olan tümevarımcı analiz ile analiz edilmiştir. Elde edilen veriler arasında anlamlı bütün oluşturanlar kod olarak tanımlanmıştır. Daha sonrasında kodlar sınıflandırılarak kategoriler oluşturulmuştur. Araştırmacılar birbiriyle ilişkili kategorileri bularak bu kategorileri birleştirip temaları ortaya çıkarmıştır. En son olarak temalara ilişkin yüzdeler ve frekanslar belirlenmiştir.

\section{Bulgular}

Bulgular bölümünde araştırma verilerinin analiz edilmesi sonucunda ortaya çıkan bulgular araştırmanın alt amaçlarıyla paralel olmak üzere sırayla sunulmuştur.

\section{Alan Seçimi Sürecinde Toplumsal Cinsiyetin Rolüne İliş̧kin Bulgular}

FeTeMM alanlarındaki kadınlara alan seçimi sırasında cinsiyetlerinin herhangi bir rolü olup olmadığına dair soru yöneltildiğinde, kadınların dokuzu $(\% 56,25)$ cinsiyetlerinin bu süreçte rol oynadığını, yedisi ise $(\% 43,75)$ cinsiyetlerinin alan seçimi sırasında etkisi olmadığını ifade etmiştir. FeTeMM alanlarını seçim sırasında cinsiyet rolünün var olduğunu ifade eden kadınların görüşlerine dair elde edilen kategoriler, frekans ve yüzdeler hâlinde Tablo 1'de verilmiştir.

FеTeMM alanlarındaki kadınların alan seçimi sırasındaki cinsiyetlerin rolüne ilişkin görüşleri incelendiğinde en fazla dile getirilen iki kategorinin "Toplum" ve "Aile" olduğu görülmektedir. Toplumdaki ve ailedeki bireylerin mesleklere ilişkin cinsiyetlendirilmiş önyargıların olması bu alanları seçmeye çalışan kadınları FeTeMM alanlarını seçme sırasında etkilemiştir. FeTeMM alanlarındaki kadınlarından biri (K4- Biyolog) alan seçimi sıra-

Tablo 1. Alan Seçimi Sürecinde Cinsiyetin Rolü

\begin{tabular}{|c|c|c|}
\hline Cinsiyet Rolü & $\boldsymbol{f}$ & $\mathbf{\%}$ \\
\hline Toplum & 5 & 33,3 \\
\hline Aile & 5 & 33,3 \\
\hline Çalışma Koşulları & 2 & 13,3 \\
\hline Mesleki Değerler & 1 & 6,7 \\
\hline Sınav Sistemi & 1 & 6,7 \\
\hline İstihdam Olanakları & 1 & 6,7 \\
\hline Toplam & $\mathbf{1 5}$ & $\mathbf{1 0 0 , 0 0}$ \\
\hline
\end{tabular}


sında mesleklere ilişkin cinsiyetleştirilmiş önyargıların var olduğunu ve toplumdan bu tarz mesajlar aldığını "Bayanlar için en uygun mesleklerden biri "öğretmenlik” ti etrafimda. Herkes ă̆ız birliği etmişçesine benim ögretmen olmamı istiyordu. Eminin onlar için bir bayana en uygun olan ögretmenliği yapsaydım her şey daha sorunsuz olurdu." ş̧eklinde ifade etmiştir. K2 (Elektrik - Elektronik Mühendisi) "Babam biraz engeldi. Çünkü etraf tarafindan erkeklerin okuduğu bölüm olarak adlandırılması ve koruma içgüdüsüyle başka bir şehirde okuyacak olmam buna sebep olmuştu." diyerek aile üyeleri meslekler ile cinsiyetlere ilişkin ön yargılı olduklarında kız çocuklarını olumsuz etkilediklerini vurgulamıştır. FeTeMM alanlarındaki kadınlar tarafından alan seçimi sırasında cinsiyetlerinin rolüne ilişkin ifade edilen diğer etkiler ise tekrarlanma sıklığına göre "Çalışma Koşulları", "Mesleki Değerler", "Sınav Sistemi” ve "İstihdam Olanakları" dır. Örneğin FeTeMM alanlarındaki çalışma koşullarının kadınların özelliklerine uygun olmayışına yönelik ön yargılar bu alanı seçme isteği olan kadınların tercihlerini etkilemektedir. K16 (Çevre Mühendisi) bu duruma ilişkin "Seçtiğim bölüm bir bayan için oldukça zor bir bölüm. Dış etkenler-arazi şartları biz bayanlara hiç uygun değil, çok zorlayıcı. Zaten ustaların, iş̧̧ilerin bakış açısı da o." demiştir.

\section{Eğitim Sürecinde Toplumsal Cinsiyetin Rolüne İlişkin Bulgular}

FeTeMM alanlarındaki kadınlara alan eğitimi sırasında cinsiyetlerinin herhangi bir rolü olup olmadığına dair soru yöneltildiğinde, kadınların altısı $(\% 37,5)$ cinsiyetlerinin bu süreçte rol oynadığını, 10'u ise $(\% 62,5)$ cinsiyetlerinin alan eğitimi sırasında etkisi olmadığını ifade etmiştir. FeTeMM alanlarında eğitim alırken cinsiyet rolünün var olduğunu ifade eden kadınların görüşlerine dair elde edilen kategoriler, frekans ve yüzdeler hâlinde Tablo 2'de verilmiştir.

FeTeMM alanlarındaki kadınlar alan eğitimi sırasında cinsiyetlerinin rolüne ilişkin ifadelerinde "Toplum" ve "Ë̆itim Yaşantıları"nın alan eğitimleri sırasında yaşantılarını ve davranışlarını etkilediklerini söylemişlerdir. Örneğin K11 (Makine Mühendisi) "Okulda 12 bayan 80'e yakın erkek vardl. Genel tavır erkeklerin bölümü olması idi. Okul, idare, ortam biraz dışlanmışlık hissettirdi. Zordu. Bizim meslek ve bölüm

Tablo 2. Eğitim Sürecinde Cinsiyetin Rolü

\begin{tabular}{|c|c|c|}
\hline Cinsiyet Rolü & $\boldsymbol{f}$ & \% \\
\hline Toplum & 3 & 30 \\
\hline Eğitim Yaşantıları & 3 & 30 \\
\hline Kişilik Özellikleri & 2 & 20 \\
\hline Staj / Çalışma Ortamı & 2 & 20 \\
\hline Toplam & $\mathbf{1 0}$ & $\mathbf{1 0 0 , 0 0}$ \\
\hline
\end{tabular}
oranının erkeklere göre daha az olmasının onların eğitim yaşantılarını olumsuz etkilediğinin altını çizmiştir. K6 (Yazılım Uzmanı) toplumda cinsiyetlere dayalı kalıplaşmış yargıların eğitim yaşantıları üzerindeki etkisini anlatırken "Yazllımcı olacăğm diye tutturunca ve kız olunca ön yargılarl yıkmakla uğraştım durdum. "Ne yapacaksın git ögretmen ol, bayan için en iyi meslek" cümleleriyle savaşmakla geçti ömrüm diyebilirim." demiştir. Bu kategorilerden sonra "Kişilik Özellikleri” (\%20) ve "Staj / Çalışma Ortamı" (\%20) FeTeMM alanlarındaki kadınlar tarafından lisans eğitimi sırasında cinsiyetleriyle ilgili etki olan faktörler arasında yer almaktadır. K9 (Çevre Mühendisi) "Staj yaparken çalışma ortamı canımı çok sıkıyordu. Bayanların teknik olarak hiçbir şey anlamadıklarını düşünüyorlardı. Bu nedenle iş yerinde teknik kadronun yardımını göremedim. Nasılsa anlayamayacağımı düşünüyorlardı.” diyerek staj/çalışma ortamlarında cinsiyetlerinden dolayı sorunlar yaşadığını ifade etmiştir. K3 (Çevre Mühendisi) ise kadınların kişilik özelliklerine ilişkin önyargılarının eğitim yaşantılarını etkilediğini şu şekilde dile getirmiştir: "Kadınlar sorunları olsa bile sorumluluklarını eninde sonunda yerine getiren insanlar olarak görülüyorlar. Bu nedenle grup ödevlerinde en çok bize 
sorumluluk veriliyordu, ama iş başarıyı paylaşmaya gelince orada kadınların hiç rolü olmuyordu".

\section{Çalışma Yaşamı Sürecinde Toplumsal Cinsiyetin Rolüne İlişkin Bulgular}

FeTeMM alanlarındaki kadınlar çalışma hayatlarında cinsiyetlerinin herhangi bir rolü olup olmadığına dair soru yöneltildiğinde, kadınların 10’u (\%62,5) cinsiyetlerinin bu süreçte rol oynadığını, altısı ise $(\% 37,5)$ cinsiyetlerinin alan eğitimi sırasında etkisi olmadığını ifade etmiştir. FeTeMM alanlarında çalışırken cinsiyet rolünün var olduğunu ifade eden kadınların görüşlerine dair elde edilen kategoriler, frekans ve yüzdeler hâlinde Tablo 3'te verilmiştir.

FeTeMM alanlarındaki kadınların çalışma hayatlarında cinsiyetlerinin rol oynama alanları sırasıyla "İ̧/_Çalışma Ortamı", "Toplum”, "Çalışma Politikaları" ve "Çalışma Koşulları" kategorileri altında toplanmıştır. FeTeMM alanlarındaki kadınlar tarafından ifade edilen ve Cinsiyet Rolü teması altında yer alan rol oynama alanları incelendiğinde en çok ( $\mathrm{f}=5)$ "Iş/Çalışma Ortamı"

Tablo 3. Çalışma Yaşamı Sürecinde Cinsiyetin Rolü

\begin{tabular}{|c|c|c|}
\hline Cinsiyet Rolü & $\boldsymbol{f}$ & \% \\
\hline İş /Çalışma Ortamı & 5 & 38,46 \\
\hline Toplum & 3 & 23,07 \\
\hline Çalışma Politikaları & 3 & 23,07 \\
\hline Çalışma Koşulları & 2 & 15,38 \\
\hline Toplam & $\mathbf{1 3}$ & $\mathbf{1 0 0 , 0 0}$ \\
\hline
\end{tabular}
kategorisine ilişkin ifadelere rastlanmıştır. FeTeMM alanlarındaki kadınlar bu alanlarda çalışırken özellikle çalışma ortamlarındaki ilişkilerinde çeşitli güçlüklerle karşılaştıklarını ve bu güçlükleri de cinsiyetlerinden dolayı yaşadıklarını ifade etmektedirler. Örneğin K7 (Jeoloji Mühendisi) çalışma hayatını "zor" olarak tanımlayıp "Genelde erkeklerin çalıştı̆̆ bir ortamda çalıştığımız için önyargılarla uğraşmak zorunda kalıyorsunuz. Bazen sırf bayan olduğum için erkeklerden daha fazla kendimi göstermek zorunda kalıyorum. Kendi işimi bırakıp insanları ikna etmeye çalışıyorum." demiştir. Kadınlara yönelik çalışma politikalarının olmayışı ya da yetersiz kalışı kadınların FeTeMM alanlarında kariyerlerini sürdürmelerine engel olmaktadır. Çünkü araştırmaya katılan FeTeMM alanlarındaki kadınlara çalışma hayatlarındaki cinsiyetlerinin rolünün hangi alanlarda ön plana çıktığı sorulduğunda kadınların üçü "Çalışma Politikaları"yla ilgili olduğu yönünde cevaplar vermiştir. Örneğin K1 (Kimyager) "Biz kadınlar doğurgan olduğumuz için sektöre başvuru sürecinde yalnızca bu özellikten dolayı elenebildiğimize bizzat şahit oldum. Çünkü doğacak olan çocuğa bakmak ülkemize maalesef yalnızca kadınların görevi olduğu için işverenler açısından potansiyel "yarın bir gün iş yapamayacak, sürekli izin alacak" şeklide değerlendirilmekteyiz." diyerek kadın olmanın biyolojik yönünün onların önüne engel olarak çıktığını belirtmektedir. K14 (Ziraat Kontrol Mühendisi) de çalışma politikalarının yetersiz oluşunun kadınlar için engel oluşturduğuna katılmakla birlikte "Dengeyi kurmak sizin elinizde. İki çocuk annesiyim, fedakâr olduğum sürece denge bozulmuyor ve çalışma hayatımı sürdürebiliyorum" diyerek kadınların ancak fedakâr olduğunda yani kendi isteklerinden vazgeçtiklerinde bu sorunun üstesinden gelebileceklerini dile getirmektedir. K15 (Malzeme Bilimi ve Mühendisi) "Özel şirketlerdeki mesai saatlerinin kadınların yaşamlarında denge kurmalarına engel olduğunu düşünüyorum. Hele bir de çalıştığımız yer oturduğumuz yerden uzak ve şehrin ulaşımı kötüyse mesai saatleri daha dayanılmaz hale geliyor. Evdeki sorumluluklarda olunca çalışma koşullarına katlanmak zorlaşıyor" diyerek "Çalışma Koşulları"nın kadınlar için zorlayıcı olduğunu vurgulamaktadır. 


\section{FeTeMM Alanlarını Seçmeyi Düşünen Kadınlara Tavsiyelere İlişkin Bulgular}

FeTeMM alanlarındaki kadınlara onlar gibi FeTeMM alanlarını seçmeyi planlayan kadınlara tavsiyelerine dair elde edilen kategoriler, frekans ve yüzdeler hâlinde Tablo 4'te verilmiştir.

FeTeMM alanlarındaki kadınlara onlar gibi FeTeMM alanlarını seçmeyi planlayan kadınlara tavsiyelerinin neler olacağına dair soru yöneltildiğinde, kadınların yedisi $(\% 30,43)$ FeTeMM alanlarındaki kadınlar kendilerini geliştirmek için eğitim alırlarsa çalışma yaşamında cinsiyetin daha az rol oynayacağını düşünmektedir. Örneğin K13 (Eğitim Teknoloğu) "Çalışma alanlarını belirledikleri andan itibaren destekleyici kurslara, etkinliklere katılmaları ve ücretli ya da ücretsiz üniversite dönemlerinde çalışma hayatına katılmalarını öneririm.” diyerek kadınların yeterliliklerini artırmaları gerektiğini ifade etmektedir. K8 (İnşaat Mühendisi) ise kadınların kendi yeteneklerini, ilgilerini bir başka deyişle kendilerini tanımalarını gerektiğini şu şekilde dile getirmiştir: "Böyle bir kariyeri hedefleyen bayanlara tek önerim hangi mühendislik dalını seçeceklerine çok dikkat etmeleri ve kendilerine en uygun mühendisliği tespit etmeleri." K10 ise "IŞs hayatı boyunca başarılı olmak için çalışmaya hevesli, ekip ile birlikte iş yapma becerisini geliştirme yönünde istekli ve ne olursa olsun pes etmeme konusunda kendilerini motive etmelerini öneririm.” diyerek kadınların kararlı durmaları yönünde tavsiye vermiştir.

\section{Tartışma ve Yorum}

\section{Alan Seçimi Sürecinde Toplumsal Cinsiyetin Rolüne İlişkin Bulguların Yorumu}

FeTeMM alanlarındaki kadınların yarısından fazlası alan seçimi sırasında cinsiyetlerinin seçme sürecini bir şekilde etkilediğini ifade etmiştir. Araştırmaya katılan kadınlar toplum ve aile üyelerinin bu alanlara yönelik cinsiyetleştirilmiş önyargıların bu süreçte olumsuz rol oynadığını dile getirmiştir. Alan yazında da bu araştırma bulgusuna paralel olarak FeTeMM alanlarının tercih edilmesi sırasında cinsiyetin rolüne ilişkin pek çok açıklama yer almaktadır (England \& Li 2006; Ceci \& Williams 2010). Kız öğrenciler bu alanları tercih ederken seçmeyi düşündüğü alanların geleneksel cinsiyet rollerine uygunluğunu test etmektedirler. Karşılaştırmalar sonucu seçeceği alanın cinsiyete yönelik yargılarla uyuşmadığını gören kız öğrenciler FeTeMM alanlarına ilgi duymaktan vazgeçmektedirler (Ceci \& Williams 2010). Bu çalışma bulguları bu bakış açısıyla değerlendirildiğinde, Türkiye'de de FeTeMM alanlarını seçen kız öğrencilerin kadınlar için uygun olmayan meslekleri seçmemeleri yönünde toplumdan ve aile üyelerinden mesajlar aldıkları söylenebilir. Bu araştırmada da FeTeMM alanlarındaki kadınlar bu alanı seçerken çevrelerinden kadınlar için uygun meslek olarak değerlendirilen "öğretmenlik" mesleğine yönelmeleri konusunda pek çok kez mesaj aldıklarını ifade etmişlerdir. Ayrıca FeTeMM alanlarında kariyer sahibi olan ebeveynlere sahip olamamak ve rol model alabilecek birini tanımamak da kadınların bu alanları kariyer olarak seçmemelerine neden olmaktadır (Ceci et al. 2015). Bu açıklamalar bu araştırmaya katılan katılımcıların yakın çevrelerinde benzer bir kariyere sahip olan, rol model alabilecekleri kişileri tanımadıklarını ipucunu sunuyor olabilir. Dolayısıyla bu araştırma bulgusunun alan yazındaki kuramsal ve uygulamalı araştırma bulgularıyla paralellik gösterdiği söylenebilir. Özellikle aileler çocukların akademik başarılarına ve yeteneklerine yö- 
nelik tutum sergilerken ya da herhangi bir söylemde bulunurken cinsiyeti ön planda tutuyorsa bu durum kız çocuklarının FeTeMM alanlarını seçmemesine neden olmaktadır (Gunderson et al. 2012; Harackiewicz et al. 2012). Bu araştırmanın katılımcıları da ailelerinin özellikle babalarının onların bu alanlarda başarılı olamayacakları yönünde söylemlerle karşılaştıklarını ifade etmektedirler.

Araştırmaya katılan kadınlar FeTeMM alanlarını seçme sürecinde ailelerinden destek alamadıklarını ifade etmişlerdir. Aile üyelerinin kadın oldukları için bu alanlarda başarılı olamayacaklarına inandıklarını ve bunu FeTeMM alanlarını seçme sürecinde sık sık dile getirdiklerini söylemişlerdir. Bu tutum ve söylemler kadınların bu alanları seçerken onların tereddüt etmesine neden olmuştur. FeTeMM alanlarındaki kadınların bu deneyimleri de araştırma bulgularıyla tutarlılık göstermektedir (Cheryan et al. 2011; Grossman \& Porche 2014).

Özetle, FeTeMM alanlarını seçme sürecinde kadınların deneyimleriyle ilgili yapılan araştırma bulguları bu çalışmanın sonuçları ışığında değerlendirildiğinde; FeTeMM alanlarına karar verme süreciyle ilgili araştırma sonuçlarının bütüncül olarak alan yazındaki bulgularla paralellik göstermektedir. Özellikle alan yazında dikkat çekilen alan seçim sürecinde aile ve toplumun rolü bu çalışma bulguları tarafından da vurgulanmaktadır. Kadın öğrencilerin bu alanları seçip seçmeme yönündeki kararları mesleklere ilişkin cinsiyetleştirilmiş kalıp yargılardan etkilenmektedir. Aile üyelerinin ve toplumdaki bireylerinin kadınların yeteneklerini ve bu alanları seçmeye yönelik isteklerini cinsiyetlerine dayalı olarak değerlendirmesi ve kalıp yargılarla bütünleştirilmiş davranışlar sergilemesi kadınların FeTeMM alanlarını seçmelerine engel olmaktadır.

\section{Eğitim Sürecinde Toplumsal Cinsiyetin Rolüne İlişkin Bulguların Yorumu}

Türkiye'de FeTeMM alanlarındaki kadınların pek çoğu $(\% 62,5)$ cinsiyetlerinin alan eğitimi sırasında herhangi bir rolünün olmadığını ifade etmiş̧tir. Kadınların alan eğitimi sırasında sorun yaşamamasının nedeni FeTeMM alanlarında öğrenim gören kadın öğrencilerin sayıca artmaya başlaması (Korkut-Owen, Kelecioğlu \& Owen 2014) olabilir. Çünkü kadın öğrenciler eğitim yaşantıları içerisinde kendilerini azınlıkta hissettiklerinde grup çalışmalarına aktif olarak katılmayı reddetmekte ve kendilerini yetkin görmedikleri için sürece kendilerini ait hissetmemektedirler (Dasgupta, Scircle \& Hunsinger 2015). FeTeMM alanlarına kendini ait hissetmeyiş, bir başka deyişle bu alanlarda varlığını sürdüremeyeceğini düşünmek düşük düzeyde özyetkinlik inançları ve akademik erteleme davranışlarıyla yakından ilişkilidir (Blake-Beard et al. 2011). Araştırma bulgusu bu doğrultuda değerlendirildiğinde, FeTeMM alanlarındaki kadınların oranının erkeklerin oranına yaklaşmış olması kadınların FeTeMM alanlarını kendilerine uygun alanlar olarak görmelerine neden olmuş olabileceği söylenebilir. Katılımcılarında da ifade ettiği gibi erkeklerin ağırlıkta olduğu mühendislik gibi alanlardaki eğitim yaşantıları ile biyoloji gibi kadınların oranının erkeklerin oranına yaklaştığı alanlarda eğitim yaşantıları farklılaşmaktadır. Erkek oranının fazla olduğu mühendislik gibi FeTeMM alanlarında cinsiyet daha fazla bir role sahiptir (Fouad \& Santana 2016; Korkut-Owen \& Mutlu 2016). Korkut-Owen ve Mutlu'nun (2016) yaptıkları araştırmanın sonucunda ortaya çıkan bulguyla paralel olarak, bu çalışmada da katılımcılar mühendislik ve teknoloji gibi erkeklerin sayıca kadınlardan daha fazla olduğu ve kadın / erkek oranları arasında büyük farkın olduğu FeTeMM alanlarında eğitim görürken cinsiyet rollerinin diğer FeTeMM alanlarına göre daha fazla etkili olduğunu düşünmektedir. Bunun nedeni Dasgupta, Scircle ve Hunsinger'in (2015) da vurguladığı gibi kadınların erkeklere göre sayıca az olduğu bölümlerde kadın öğrenciler cinsiyetlerinden dolayı kendilerini bu alana ait hissetmemeleri olabilir. Ayrıca eğitim alma sürecinde cinsiyetlerinin rolü olduğunu düşünen FeTeMM alanlarındaki kadınlar toplumdaki bireylerden toplumsal cinsiyet rollerine uygun alanlarda eğitim görmeleri yönünde mesajlar aldıklarını ve eğitim yaşantıları sürecinde okul içi 
ve dışında cinsiyet farklılıklarına ilişkin kalıp yargılarla bütünleştirilmiş davranışlarla karşılaştıklarını ifade etmektedirler. Muhtemelen Meadows ve Sekaquaptewa'nın (2011) da dikkat çektiği gibi bu tür tutum, davranış ve mesajlar bu araştırmaya katılan kadınların öz-yeterlilik inançlarını olumsuz yönde etkilediği için FeTeMM alanlarında eğitim almaya devam edip etmeyecekleri yönündeki kararını da olumsuz yönde etkilemektedir (Meadows \& Sekaquaptewa 2011).

FeTeMM alanlarındaki kadınların alan eğitimi sırasında sorun yaşamamasının bir başka nedeni ortaöğretim kademesindeki öğrenme yaşantıları (Fouad \& Santana 2016) olabilir. Çünkü öğrencilere öğrencilerin öğrenme yaşantıları sırasında öğrenmelerini kalıcı hale getirecek ve onların FeTeMM alanlarıyla ilgili özyetkinlik inançlarını artıracak etkinliklerin sunulması onların bu alanları seçmelerine ve bu alanlarda eğitim görmeye devam etmelerine olumlu yönde etkilemektedir (Navarro, Flores \& Worthington 2007; Fouad \& Santana 2016). Bir başka deyişle, araştırmaya katılan katılımcıların sorun yaşamama nedenleri arasında destekleyici öğrenme yaşantıları olabilir. Öğrenme yaşantıları sayesinde bu alana ilişkin özyetkinlik inanç ve mesleki sonuç beklenti düzeyleri cinsiyetten bağımsız bir biçimde arttığı için FeTeMM alanlarında kariyerlerini sürdürebileceklerine inanmaktadırlar. Bu şekilde eğitim alma sürecinde erkekler gibi bu alanlarda eğitimlerini sürdürmektedirler.

Özetle, FeTeMM alanlarında eğitim gören kadınlar cinsiyetlerinin farklı biçimlerde kariyer gelişimlerini etkilediğini ifade etmektedirler. Araştırmaya katılan kadınların çoğunluğu cinsiyetlerinin rolünün olmadığını düşünürken bir bölümü de cinsiyetlerinin rolü olduğunu düşünmektedir. FeTeMM alanlarındaki kadınların cinsiyetlerinin rolü ve rol oynama biçimi kadınların öğrenim gördüğü $F e T e M M$ alanlarındaki yapıya (erkek oranı, öğretim üyelerinin tutumu, öğrenme yaşantıları gibi) göre değişebilmektedir. Araştırmanın bu bölümünde asıl dikkat çeken nokta ise cinsiyetlerinin rolü olduğunu düşünen kadınların toplumdan gelen mesajları vurgulamalarıdır. Bu araştırmaya katılan kadınlar özellikle eğitim yaşantıları sırasında sınıf arkadaşlarının, öğretmenlerinin ve ailelerinin tutum ve davranışlarının FeTeMM alanda kariyerlerini sürdürmeye yönelik motivasyon düzeylerinin düşürdüklerini ifade etmişlerdir.

\section{Çalışma Yaşamında Toplumsal Cinsiyetin Rolüne İlişsin Bulguların Yorumu}

Araştırmaya katılan FeTeMM alanlarındaki kadınların \%62,5’i cinsiyetlerinin çalışma yaşamlarında rol oynadığını ifade etmişlerdir. Katılımcılar özellikle cinsiyetlerin iş yaşamında onlara güçlük çıkardığını dile getirmektedirler. Bu bulgu FeTeMM alanlarındaki kadınların kariyer gelişimleri süresince deneyimledikleri pek çok araştırmayı (Esin \& Öztürk 2005; Cha 2010) destekler niteliktedir. Örneğin çalışma ortamında iş ilişkileri içerisinde erkeklerin kadınlara ilişkin cinsiyete dayalı kalıp yargıları ve bu nedenle kadınlar ihtiyaç duysa dahi destek vermeyişleri (Xu 2015) kadınların cinsiyetinin çalışma yaşamında da rol oynadığını göstermektedir.

FeTeMM alanlarında çalışan kadınların hem evde hem de işte yükümlülüklerinin olması ve bu yükümlülüklerin azaltılması için destek bulamayışları (Cha 2010; Glass et al. 2013) bu araştırmadaki katılımcıların dile getirdiği çalışma yaşamlarındaki cinsiyetlerin rolüne ilişkin ifadelerden birisidir. Bu bulgunun bu araştırmada ortaya çıkmasının sebebi gelişen dünyada koşulların değişmesiyle birlikte kadınların geleneksel aile içi rolünün yanına bir de sosyal ve ekonomik yaşamdaki rollerinin eklenmesi (Kocacık \& Gökkaya 2005) olabilir. Hali hazırda ev içi sorumluluklarını yerine getirmekle yükümlü görülen kadınlardan bir de ekonomik ve sosyal yaşamlarında kendilerinden bekleneni yerine getirmeleri istenmektedir. Kadınların yakın ve uzak çevrelerinde yer alan bireylerin kadınlardan hem ev hem de işteki sorumluluklarını yerine getirmeleri yönündeki bu cinsiyetçi önyargılar kadınları işgücü piyasasından uzaklaştırmaktadır (Parlaktuna 2010). Ayrıca ekonomik anlamda zarara uğrayan kadınlara bu beklentilerin kar- 
ş1lanması sürecinde psikolojik, sosyal ve ekonomik anlamda destek sunacak bireyler ve kurumlar da sinırlıdır. Dolayısıyla bu araştırmaya katılan kadınların kendilerinden beklenenleri gerçekleştirmek konusunda güçlük çektikleri ve bunun bir sonucu olarak da bu alanlardaki kariyerlerini sürdürmek konusunda sıkıntı yaşadıkları söylenebilir.

$\mathrm{Bu}$ araştırmaya katılan FeTeMM alanlarındaki kadınlara benzer olarak çalışma hayatında yer alan pek çok kadının cinsiyetlerinden dolayı bazı problemlerle karşılaştıkları söylenebilir. Özellikle evli ve çocuklu olan kadınların çalışma yaşamında güçlük çektikleri (Parlaktuna 2010) alan yazında vurgulanmaktadır. $\mathrm{Bu}$ araştırmada da kadınlar iş ilişkilerinde cinsiyetlerden dolayı farklı yaklaşımlarla karşılaştıklarını ama bu yaklaşımların onların motivasyon düzeyini düşürdüklerini ifade etmişlerdir. Evli ve çocuklu kadınlar olarak iş yaşamında güçlük çektiklerini, bu güçlüklerle karşılaştıklarında destek bulamadıklarını ve çalışma politikalarının kadınların ihtiyaçlarına göre iyileştirilmesi gerektiğini düşündüklerini ifade etmişlerdir. Küçükşen ve Kaya (2016) tarafindan yapılan bir çalışmada yönetici olarak çalışan kadın akademisyenlerle çalışılmıştır. Araştırma sonunda kadın katılımcıların iş, aile özel alan dengesini kurabilmek için kendi kişisel, özel ihtiyaçlarından (uyku, eğlence, dinlenme, sağlık gibi) ödün verdikleri bulunmuştur. Bu ifadelerden yola çıkarak bu sorunlara çalışılan alanın değil kadın olmanın yol açtığı söylenebilir.

Sonuç olarak, FeTeMM alanlarındaki kadınların sorunları ile çalışma hayatında yer alan ekonomik yaşamda rolleri olan kadınların sorunları birbirine benzerlik göstermektedir. Kadınların çalışma hayatlarında sorunlar yaşamalarının nedenleri kültürel, ekonomik, bilimsel vd. pek çok alanlardaki gelişimlere dayalı olarak meydana gelen değişimlerle açıklanabilir. Bununla birlikte bu noktada nedenler kadar kadınların çalışma hayatlarında iş ilişkilerinde cinsiyetlerine bağlı olarak farklı davranış ve tutumlarla karşılaştıklarında, bu tutum ve davranışların yol açtığ 1 güçlüklerle baş etmeye çalıştıklarında ve ya baş edemediklerinde destek sunacak mekanizmaları aradıklarında sunulacak çözüm yollarının bulunması da önemlidir.

\section{FeTeMM Alanlarını Seçmeyi Düşünen Kadınlara Tavsiyelere İlişkin Bulguların Yorumu}

FeTeMM alanlarındaki kadınlara onlar gibi FeTeMM alanlarını seçmeyi planlayan kadınlara tekrarlanma sıklığına göre; eğitim almaları $(\mathrm{f}=7)$, kendilerini tanımalarını $(\mathrm{f}=6)$, kararları durmaları ( $\mathrm{f}=4)$, kendilerine güvenmeleri $(\mathrm{f}=2)$, yaşamlarını düzenlemelerini $(\mathrm{f}=2)$, rekabete hazırlıklı olmalarını $(\mathrm{f}=1)$ ve seçim haklarını kullanmalarını $(\mathrm{f}=1)$ tavsiye etmektedir. FeTeMM alanlarındaki kadınların bu alanı seçmeyi planlayan kadınlara verdikleri tavsiyeler bütüncül olarak değerlendirildiğinde, kadınların tavsiyelerinin kendi deneyimlerine dayandığı söylenebilir. Özellikle erkeklerin kadınlara oranla sayıca fazla olduğu alanlarda kadınlar kendilerini ispatlamak için çok çaba sarf etmektedirler (Dasgupta, Scircle \& Hunsinger 2015). Hâlihazırda var olan kadınlara yönelik cinsiyete dayalı kalıp yargılarla (kadınların erkek egemen meslekleri yapamayacağı gibi) mücadele eden kadınlar (Xu 2015) çalışma ortamında ya da eğitim yaşantıları sırasında kendilerini ispatlamak ve potansiyellerini gösterebilmek için erkeklere göre daha fazla çabalamaları gerekmektedir. Bu nedenle FeTeMM alanlarındaki kadınlar bu alanda çalışan kadınlara eğitim almaları yönünde tavsiye vermiş olabilir.

Moakler ve Kim (2014) FeTeMM alanlarındaki kadınların bu alanlarda kariyer gelişimlerini sürdürülebilmesi için kadın öğrencilere destekleyici öğrenme yaşantılarının ve bu alanlara ilişkin öz-yetkinlik inançlarını arttıracak materyallerle desteklenen öğretimin eğitimin vazgeçilmez unsurları olması gerektiğini ifade etmektedir. Bu açıklama doğrultusunda katılımcıların görüşleri değerlendirildiğinde $F e T e M M$ alanlarındaki kadınların bu eğitim sürecine dâhil olduğu ve bu alanı seçecek kadınlara da kararları durmaları $(\mathrm{f}=4)$ ve kendilerine güvenmeleri $(\mathrm{f}=2)$ yönünde tavsiyeler verdikleri görülmektedir. FeTeMM alanlarındaki kariyer gelişimlerini sürdüre- 
bilmelerini kendilerine olan güvenleriyle ve kararlı duruşlarıyla açıklayan kadınlar bu alanı seçmeyi düşünen kadınlara da bu yönde tavsiyeler sunmuş olabilir.

Sonuç olarak, FeTeMM alanlarında kariyer gelişimlerini sürdüren kadınlar kariyer gelişimleri süresince alanlarını seçerken, bu alanlarda eğitim görürken ve çalışırken karşılaştıkları güçlükleri göz önünde bulundurarak tavsiyelerde bulunmuşlardır. Toplumsal ve bireysel düzeyde cinsiyete dayalı kalıp yargılarla karşılaşan kadınlar kariyer gelişimleri süresince bu sorunlarla baş etmeye çalışmaktadırlar. Dolayısıyla onlar gibi FeTeMM alanlarında kariyer yapmayı düşünen kadınlara yol göstermek adına deneyimlerini paylaşmaktadırlar. Bu deneyimler doğrultusunda da tavsiye vermektedirler.

\section{Sonuç ve Öneriler}

Araştırmada FeTeMM alanlarındaki kadınların cinsiyetlerinin alan seçimi sırasında en çok toplumsal değerler ve aile üyeleri, alan eğitimi sırasında toplumsal değerler ve eğitim yaşantıları, çalışma yaşamlarında iş/çalışma ortamı ve toplumsal değerler aracığıyla kariyer gelişimleri üzerinde rol oynadığı bulunmuştur. FeTeMM alanlarındaki kadınlar bu alanlarda kariyer yapacak kadınlara en çok eğitim almaları ve kendilerini tanımları yönünde tavsiyeler vermiştir.

Araştırmanın bulguları incelendiğinde, pek çok katılımcının mesleklere ve cinsiyetlere yönelik kalıplaşmış algıların, tutumların ve değerlerin Türkiye'de FeTeMM alanlarındaki kadınların meslek seçimlerinde, eğitim yaşantılarında ve çalışma hayatlarında rol oynadıklarını ifade ettikleri görülmektedir. Bu noktada toplumdaki mesleklere ya da cinsiyetlere yönelik kalıplaşmış yargıların azaltılması için toplumsal cinsiyete dayalı politikaların oluşturulması öneri olarak getirilebilir. Özellikle iş dünyasında işe alım, işte yükselme ve izin gibi kadınların cinsiyetlerinin ön plana alınabileceği noktalarda devreye giren politikaların yeniden gözden geçirilmesi, sorunların ve ihtiyaçların belirlenmesi etkili ve eşitlikçi politikaların var olmasına katkı sağlayabilir.

İhtiyaçların ve sorunların belirlenmesi aşamasında FeTeMM alanlarındaki kariyeri olan herkesin bu alana ilişkin görüşlerinin alınabilmesi için alan çalışanlarına ve sivil toplum kuruluşlarına ihtiyaç vardır. Bu noktada kadınların meslektaşlarıyla networkunun geliştirilmesi ve sivil toplum kuruluşlarına üye olmaları için teşvik edilmesi öneri olarak getirilebilir. Hem alan çalışanları hem de sivil toplum kuruluşlarına üyelik aracılığıyla sadece alan sorunları belirlenmeyecek aynı zamanda da kadınlara verilen destek artmış olacaktır. Araştırmaya katılan kadınların da belirttiği gibi kariyerleri süresince destek görenler motivasyonları artarak bu alana kendilerini daha uygun bulmaktadırlar.

Araştırmanın bulguları mesleki rehberlik ve kariyer psikolojik danışmanlığı açısından düşünüldüğünde, okullardaki ruh sağlığı uzmanları araştırma bulgularını göz önünde bulundurarak mesleki rehberlik ve kariyer psikolojik danışmanlığı kapsamındaki hizmetleri planlayabilir. Söz konusu hizmetler arasında; FeTeMM alanlarında çalışan kadınlar ile bu alanları seçmeyi düşünen kız öğrencileri bir araya getiren etkinlikler düzenleme, alan seçimi sırasında bireysel özelliklerinin tanımanın önemi hakkında seminer verme, toplumsal cinsiyet rollerine ilişkin farkındalık ve FeTeMM alanlarıyla ilgili özyetkinlik ve mesleki sonuç beklenti düzeylerini artırmaya yönelik programları geliştirme ve uygulama, FeTeMM alanlarını seçmeyi düşünen öğrencileri cesaretlendirme yer alabilir. Özellikle bu alanı seçme sürecinde öğrencilerin bu alanlara ilişkin özyetkinlik inançlarının ve temel düzeydeki bilgilerin kazanıldığı düşünüldüğünde mesleki rehberlik ve kariyer psikolojik danışmanlığı kapsamındaki hizmetlerinin ortaöğretim kademesinde yoğunlaştırılması öneri olarak getirilebilir.

Araştırma bulguları FeTeMM alanlarındaki kadınların kariyer gelişimleriyle ilgili yapılan 
araştırmaların yer aldığı alan yazına katkı sağlamıştır. Kadınların FeTeMM alanlarını seçerken, bu alanlarda eğitim görürken ve çalışırken toplumsal cinsiyetleri bağlamında ne tür sorunlarla karşılaştığına dair ortaya çıkan bulgular alan yazına katkı sağlamıştır. Öte yandan çalışmada ortaya çıkan bulgular araştırmacıların ulaşabildiği FeTeMM alanlarında çalışan 16 kadın ile sınırlıdır. Dolayısıyla bundan sonra yapılacak araştırmalar daha büyük ölçekte düzenlenip elde edilecek bulgular daha büyük bir kitleye genellenebilir. Bu şekilde FeTeMM alanlarındaki kadınların kariyer gelişimleri daha geniş bir perspektifte ele alınabilir. Ayrıca bu araştırmada elde edilen bulgular nitel veri toplama araçları kullanılarak elde edilmiştir. Fakat görüşmeler sonucunda daha büyük kadın gruplarının kariyer gelişimlerinin incelenmesi gerekliliği ortaya çıkmıştır. Bu nedenle bundan sonra yapılacak araştırmalarda bu araştırmadaki görüşmelerden elde edilen bulgular göz önünde bulundurularak daha büyük kadın gruplarına yollanabilecek ölçme aracı (anket ya da ölçek) geliştirilebilir.

Araştırma bulguları FeTeMM alanlarında kariyerini sürdüren Türkiye'de öğrenim görmüş ve yaşayan kadınların görüşlerine dayalı olarak bulunmuştur. Dolayısıyla araştırma sonuçları Türkiye’deki öğrenim görüyor, görecek ve görmüş olan, ayrıca bu alanlarda hâlihazırda çalışan kadınların görüşlerini yansıtmaktadır. Türkiye'deki FeTeMM alanlarında çalışan kadınların kariyer gelişimlerini yansıtmayı amaçlayan bu araştırmada araştırma bulguları FeTeMM alanlarında çalışan kadınların kariyer gelişimlerini yansıtabilmesi için FeTeMM alanlarının her birinde çalışan en az bir kadın katılımıının görüşlerine yer verilmiştir. Bununla birlikte Fouad ve Santana'nın (2016) da belirttiği gibi son zamanlarda mesleki rehberlik ve kariyer psikolojik psikolojik danışmanlığı alan yazınında mühendislik alanında çalışan kadınların kariyer gelişimlerini çeşitli kuramsal yaklaşımdan inceleyen araştırmalar sayıca giderek artmaktadır. Araştırmalar kadınların FeTeMM alanlarında nasıl sorunlarla karşılaştıklarını ve neden bu alanlarda kariyerlerini sürdürdüklerini anlamaya yönelik (Buse, Bilimora \& Perelli 2013) tasarlanmıştır. Buradan yola çıkarak, araştırmacılara ileri araştırmalar yapılandırırken bu hususa dikkat etmeleri önerilebilir. Her bir FeTeMM alanında çalışan kadınların kariyer gelişimleri sırasında algıladıkları destekleri, engelleri ve sorunları analiz edecek araştırmalar alanyazına katkı sağlayabileceği gibi aynı zamanda da kadınların bu alanlardaki varlıklarını sürdürmeleri için teşvik edebilir.

\section{KAYNAKÇA}

Accenture (2014, Eylül 16). Powering Economic Growth; Attracting More Young Women into Science and Technology. Kaynak: https://www.accenture.com/ie-en/ /media/Accenture/Conversion-Assets/ DotCom/Documents/Global/PDF/Industries_14/Accenture-STEM-Powering-Economic Growth.pdf.

Akgündüz D. \& Ertepınar H. (2015, Temmuz 16). "STEM Eğitim Raporu”.

American Association of University Women (AAUW). (2010, Temmuz 15). Why So Few? Women in Science, Technology, Engineering, and Mathematics. Kaynak: https://www.aauw.org/files/2013/02/ Why-So-Few-Women-in-Science-Technology-Engineering-and-Mathematics.pdf

Bandura A. (1977). Social Learning Theory. Englewood Cliffs 1977.

Başaran-Symes C. (2015, Ağustos 16). Eğitimde Yeni Trendler: STEM Konferansı. Kaynak: http://tusiad. org/tr/konusma-metinleri/item/8428-tusiad-yonetim-kurulu-baskani-cansen-basaran-symesin-eitimdeyeni-trendler-stem-konferansi-acilis-konusmasi

Bem S. L. (1983). "Gender Schema Theory and Its Implications for Child Development: Raising GenderAschematic Children in a Gender-Schematic Society”. Signs 8/4 (1983) 598-616. Doi: 10.1086/493998.

Blake-Beard S., Bayne M. L., Crosby F. J. \& Muller C. B. (2011). "Matching by Race and Gender in Mentoring Relationships: Keeping Our Eyes on The Prize". Journal of Social Issues 67/3 (2011) 622-643.

Brandt R. (2014, Temmuz 2015). Why Do Undergraduate Women Persist as STEM Majors? A Study at Two Technological Universities. Kaynak: http://scholarship.shu.edu/cgi/viewcontent.cgi?article=294 
6vecontext $=$ dissertations

Burchinal M. R., Roberts J. E., Zeisel S. A. \& Rowley S. J. (2008). "Social Risk and Protective Factors for African American Children's Academic Achievement and Adjustment During the Transition to Middle School”. Developmental Psychology 44 (2008) 286-292.

Buse K., Bilimoria D. \& Perelli S. (2013). "Why They Stay: Women Persisting in US Engineering Careers”. Career Development International 18/2 (2013) 139-154.

Ceci S. J., Ginther D. K., Kahn S. \& Williams W. M. (2015). "Women in Science: The Path to Progress”. Scientific American Mind 26/1 (2015) 62-69.

Ceci S.J. \& Williams W.M. (2010). "Sex Differences in Math-Intensive Fields". Current Directions in Psychological Science 19 (2010) 275-279.

Cha Y. (2010). “Reinforcing Separate Spheres: The Effect of Spousal Overwork on Men's and Women's Employment in Dual-Earner Households”. American Sociological Review 75 (2010) 303-329.

Chen X. \& Weko T. (2009, Temmuz 15). Students Who Study Science, Technology, Engineering, and Mathematics (STEM) in Postsecondary Education (NCES 2009-61). Washington, DC: National Center for Education Statistics. Kaynak: http://www.cslnet.org/wp-content/uploads/2013/07/Stats-inBrief-Students-who-Study-STEM.pdf

Cheryan S., Siy J. O., Vichayapai M., Drury B. J. \& Kim S. (2011). "Do Female and Male Role Models Who Embody STEM Stereotypes Hinder Women's Anticipated Success in STEM?”. Social Psychological and Personality Science 2/6 (2011) 656-664.

Chodorow N. (1998). "Gender, Relations and Difference in Psychoanalytic Perspective”. The Polity Reader in Gender Studies (1998) 41-49. Oxford.

Cramer S. H., Herr E. L. \& Niles S. G. (2004). Career Guidance and Counseling through the Lifespan. Boston 2004.

Dasgupta N. \& Stout J.G. (2014). "Girls and Women in Science, Technology, Engineering, and Mathematics Steming The Tide and Broadening Participation in STEM Careers". Policy Insights from the Behavioral and Brain Sciences 1/1 (2014) 21-29.

Dasgupta N., Scircle M. M. \& Hunsinger M. (2015). "Female Peers in Small Work Groups Enhance Women's Motivation, Verbal Participation, and Career Aspirations in Engineering”. Proceedings of the National Academy of Sciences 112/6 (2015) 4988-4993.

Deaux K. \& Major B. (1987). "Putting Gender into Context: An Interactive Model of Gender-Related Behavior”. Psychological Review 94/3 (1987) 369-389.

Deemer E. D., Thoman D. B., Chase J. P. \& Smith J. L. (2014). "Feeling the Threat Stereotype Threat As A Contextual Barrier to Women's Science Career Choice Intentions”. Journal of Career Development 41/2 (2014) 141-158.

Dökmen Z. (2004). Toplumsal Cinsiyet, Sistem Yayıncıllk. İstanbul 2004.

Eagly A. (1987). Sex Differences in Social Behavior: A Social-Role Interpretation. Hillsdale 1987.

England P. (2010). “The Gender Revolution: Uneven and Stalled”. Gender and Society 24/2 (2010) 149-166.

England P. \& Li S. (2006). "Desegregation Stalled: The Changing Gender Composition of College Majörs: 1971-2002”. Gender and Society 20/5 (2006) 657-677.

Ercan H. (2011, Temmuz 13). Türkiye’de Mesleki Görünüm. Uluslararası Çalışma Örgütü. Kaynak: http://www.tr.undp.org/content/dam/turkey/docs/projectdocuments/PovRed/MDG_F_1928/UNDPTR-YEM_Mesleki\%20Gorunum_Basim_TR.pdf

Esin N. \& Öztürk N. (2005). "Çalışma Yaşamı ve Kadın Sağlı̆̆ı”. TTB Mesleki Sağllk ve Güvenlik Dergisi (2005) 38-42.

Fouad N. A., Hackett G., Smith P. L., Kantamneni N., Fitzpatrick M., Haag S. \& Spencer D. (2010). "Barriers and Supports for Continuing in Mathematics and Science: Gender and Educational Level Differences”. Journal of Vocational Behavior 77/3 (2010) 361-373.

Fouad N. \& Santana M.C. (2016). "SCCT and Underrepresented Populations in STEM Fields Moving the Needle”. Journal of Career Assessment (2016) 1-16.

Giddens A. (2012). Cinsellik ve toplumsal cinsiyet. Sosyoloji (2012) 478-527. İstanbul. 
Glass J. L., Sassler S., Levitte Y. \& Michelmore K. M. (2013). "What's So Special about STEM? A Comparison of Women's Retention in STEM and Professional Occupations”. Social Forces 92/2 (2013) 723-756.

Grossman J. M. \& Porche M. V. (2013). "Perceived Gender and Racial/Ethnic Barriers to STEM Success”. Urban Education 49/6 (2013) 698-727

Gunderson E. A., Ramirez G., Levine S. C. \& Beilock S. L. (2012). "The Role of Parents and Teachers in the Development of Gender-Related Math Attitudes”. Sex Roles 66/3-4 (2012) 153-166.

Haki C. (2002). "Lifestyle Preferences as Determinants of Women's Differentiated Labor Market Careers". Work and Occupations 29 (2002) 428-459.

Harackiewicz J. M., Rozek C. S., Hulleman C. S. \& Hyde J. S. (2012). "Helping Parents to Motivate Adolescents in Mathematics and Science an Experimental Test of a Utility-Value Intervention". Psychological Science 23 (2012) 899-906.

Hartman H. \& Hartman M. (2008). "How Undergraduate Engineering Students Perceive Women's (And Men's) Problems in Science, Math And Engineering”. Sex Roles 58 (2008) 251-265.

Inda M., Rodriguez C. \& Peňa J.V. (2013). "Gender Differences in Applying Social Cognitive Career Theory in Engineering Students”. Journal of Vocational Behavior 83 (2013) 346-355.

Johnson H. J., Barnard-Brak L., Saxon T. F. \& Johnso M. K. (2012). "An Experimental Study of the Effects of Stereotype Threat and Stereotype Lift on Men and Women's Performance in Mathematics". Journal of Experimental Education 80 (2012) 137-149.

Kiwana L., Kumar A. \& Randerson N. (2011, Ağustos 13). An Investigation into Why the UK Has the Lowest Proportion of Female Engineers in the EU. Kaynak: http://www.engineeringuk.com

Kocacık F. \& Gökkaya V. (2005). "Türkiye'de Çalışan Kadınlar ve Sorunları”. Cumhuriyet Üniversitesi İktisadi ve İdari Bilimler Dergisi 6/1 (2005) 195-219.

Korkut- Owen F. Kelecioğlu H. \& Owen D. W. (2014). "Cinsiyetlere Göre Üniversitelerdeki On Bir Yıllık Eğilim: Kariyer Danışmanlığı için Doğurgular”. International Journal of Human Sciences 11/1 (2014) 794-813.

Korkut-Owen F., Kepir D. D., Özdemir S., Ulaş Ö. \& Yılmaz O. (2012). "Üniversite Öğrencilerinin Bölüm Seçme Nedenleri”. Mersin Üniversitesi Eğitim Fakültesi Dergisi 8/3 (2012) 135-151.

Korkut-Owen F. \& Mutlu T. (2016). “Türkiye'de Fen Bilimleri, Teknoloji, Mühendislik ve Matematik Alanlarının Seçiminde Cinsiyetler Arası Farklılıklar”. Yaşadıkça Eğitim 30/2 (2016) 53-72.

Küçükşen K. \& Kaya Ş.D. (2016). "Yönetici pozisyondaki Akademisyen Kadınlarda Aile -İş- Özel Yaşam Dengesi”. Akademik Sosyal Araştırmalar Dergisi 4/37 (2016) 662-674.

Leaper C. \& Brown C. S. (2008). "Perceived Experiences with Sexism Among Adolescent Girls". Child Development 79 (2008) 685-704.

Lent R.W., Brown S. D. \& Hackett G. (1994). "Toward a Unifying Social Cognitive Theory of Career and Academic Interest, Choice, and Performance”. Journal of Vocational Behavior 45 (1994) 79-122.

Lent R. W. \& Brown S. D. (2002). "Social Cognitive Career Theory and Adult Career Development”. Ed. S. G. Niles, Adult Career Development: Concepts, Issues and Practices $\left(2002^{3}\right)$ 76-97. Columbus.

Lent R. W., Sheu H., Gloster C. S. \& Wilkins G. (2010). "Longitudinal Test of the Social Cognitive Model of Choice in Engineering Students at Historically Black Universities”. Journal of Vocational Behavior 76 (2010) 387-394.

Martin C. L. (1993). “New Directions for Investigating Children’s Gender Knowledge”. Developmental Review 13 (1993) 184-204.

Martin C. L. \& Halverson C. (1981). "A Schematic Processing Model of Sex Typing and Stereotyping in Children”. Child Development 52 (1981) 1119-1134.

Meadows L. \& Sekaquaptewa D. (2011, Temmuz 16). "The Effect of Skewed Gender Composition on Student Participation in Undergraduate Engineering Project Teams". Proceedings of the Association for Engineering Education (ASEE) Annual Conference, Vancouver, BC 2011. Kaynak: www.asee. org/public/conferences/1/papers/1319/view

Moakler M. W. \& Kim M. M. (2014). "College Major Choice in STEM: Revisiting Confidence and 
Demographic Factors”. The Career Development Quarterly 62 (2014) 128-142

Moss-Racusin C. A., Dovidio J. F., Brescoll V. L., Graham M. J. \& Handelsman J. (2012). "Science Faculty's Subtle Gender Biases Favor Male Students”. Proceedings of the National Academy of Sciences 109/41 (2012) 16474-16479.

Mueller C. E., Hall A. L. \& Miro D. Z. (2015). “Testing an Adapted Model of Social Cognitive Career Theory: Findings and Implications for a Self-Selected, Diverse Middle-School Sample”. Journal of Research in STEM Education 1/2 (2015) 142-155.

Murphy M. C., Steele C. M. \& Gross J. J. (2007). "Signaling Threat: How Situational Cues Affect Women in Math, Science, and Engineering Settings”. Psychological Science 18/10 (2007) 879-885.

National Science Foundation, National Center for Science and Engineering Statistics (2015, Mayls 16). Women, Minorities, And Persons With Disabilities in Science and Engineering: 2015. Special Report NSF No. 15-311. Arlington, VA. Kaynak: https://www.nsf.gov/statistics/2015/nsf15311/digest/nsf15 311-digest.pdf

National Science Foundation, National Center for Science and Engineering Statistics (2010, Şubat 16). Science And Engineering Indicators 2010 (NSB 10-01). Arlington, VA: National Science Foundation. Kaynak: https://www.mtu.edu/research/administration/sponsored-programs/enhancement/pdf/scienceengineering-indicators.pdf

Navarro R. L., Flores L.Y. \& Worthington R. L. (2007). "Mexican American Middle School Students' Goal Intentions in Mathematics and Science: A Test of Social Cognitive Career Theory”. Journal of Counseling Psychology 54/3 (2007) 320-335.

Nosek B. A., Banaji M. R. \& Greenwald A. G (2002). "Math = Male, Me = Female, therefore Math $\neq$ Me”. Journal of Personality and Social Psychology 83 (2002) 44-59.

Okay N. (2013). BMT Kadın Araştırmaları Merkezi. CEBIT Bilişim Eurasua, 24-26 Ekim 2013, WOW Konferans Merkezi, İstanbul. Kaynak: http://cebitsinerji.com/kategori/ekim-25

Ost B. (2010). “The Role of Peers and Grades in Determining Major Persistence in Sciences”. Economics of Education Review 29/6 (2010) 923-934.

Parlaktuna İ. (2010). “Türkiye'de Cinsiyete Dayalı Mesleki Ayrımcılığın Analizi”. Ege Akademik Bakış 10/4 (2010) 1217-1230.

Perez-Felkner L., McDonald S. K., Schneider B. \& Grogan E. (2012). “Female and Male Adolescents’ Subjective Orientations to Mathematics and the Influence of Those Orientations on Postsecondary Majors”. Developmental Psychology 48 (2012) 1658-1673.

Schelmetic T. (2013). Where are America's women engineers?”. Kaynak: http://news.thomasnet.com/imt /2013/02/19/where-are-americas-women-engineers

Simard C. (2008). Climbing the Technical Ladder: Obstacles and Solutions for Mid-Level Women in Technology. Kaynak: http://gender.stanford.edu/sites/default/files/Climbing_the_Technical_Ladder.pdf

Su R., Rounds J. \& Armstrong P. I. (2009). "Men and Things, Women and People: A Meta-Analysis of Sex Differences in Interests”. Psychological Bulletin 135 (2009) 859-894.

Wang M. \& Degol J. (2014). "Motivational Pathways to STEM Career Choices: Using ExpectancyValue Perspective to Understand Individual and Gender Differences in STEM Fields”. Developmental Review 33 (2014) 304-340.

Xu Y. (2015). "Focusing on Women in STEM: A Longitudinal Examination of Gender-Based Earning Gap of College Graduates.” The Journal of Higher Education 86 (2015) 489-523.

Yıldırım A. \& Şimşek H. (2013). Sosyal Bilimlerde Nitel Araştırma Yöntemleri. İstanbul $2013^{6}$.

Terzioğlu F. \& Taşkın L. (2008). "Kadının Toplumsal Cinsiyet Rolünün Liderlik Davranışlarına ve Hemşirelik Mesleğine Yansımaları”. C. Ü. Hemşirelik Yüksekokulu Dergisi 12/2 (2008) 62-67.

Wang M. \& Degol J. (2013). "Motivational Pathways to STEM Career Choices: Using Expectancy-Value Perspective to Understand Individual and Gender Differences in STEM Fields”. Developmental Review 33/4 (2013) 304-340. 